\title{
Impact of Brand Community Participation on Brand Equity Dimension in Luxury Apparel Industry - A Structural Equation Modeling Approach
}

\author{
Muhammad Adnan Bashir * $\quad$ Nadia Ayub Ali ${ }^{\dagger} \quad$ Tariq Jalees ${ }^{\ddagger}$
}

\begin{abstract}
The role of consumers in brand management is increasing day by day due to rapid advancements in technology. Communication related to brand has been shifted from one-way (unidirectional) communication (mass marketing) to two-way (bidirectional) communication through social media. Hence, researchers and marketers are putting their utmost efforts to explore and understand the phenomenon. Present study is aimed to measure the impact of online brand community participation on brand equity elements. Conceptual framework was developed based on the available literature. Data was collected form 1811 respondents who were the students of different business schools at Karachi. We took the constructs and scale items from previous studies. Reliability and validity were re-ascertained. SEM was applied through AMOS. Results showed that participation in online brand communities has significant impact on the three brand equity dimensions i.e. "brand awareness, brand association, and perceived quality". Both brand association and brand perceived quality significantly affect the brand loyalty. The relationship between consumer brand awareness and consumer brand loyalty was insignificant. The findings revealed a good overall model fit as the fit indices were meeting the required values.
\end{abstract}

Keywords: Brand community participation, brand awareness, brand association, perceived quality, brand loyalty.

\section{Introduction}

With its increased usage (3.196 billion social media users in 2018) and higher user rate (6 hours of internet usage each day), social media facilitate its users in maintaining social relationships with each other by providing an easy-to-use interface (Akrout \& Nagy, 2018; Ngai, Tao, \& Moon, 2015). Social media has revamped consumers approach towards buying, generally consumers rely more on what other users are saying about the brand, as they are well aware of technology and virtually connected to each other and discuss many things about brands (Laroche, Habibi, \& Richard, 2013). It has been observed that fan pages of the brands are increasing because companies are attempting to reach customers using social media so that their problems can be resolved timely. Organizations are increasingly

\footnotetext{
*Institute of Business Management - Marketing, Karachi, Pakistan.

†Institute of Business Management - Psychology, Karachi, Pakistan.

${ }_{\ddagger}^{\ddagger}$ PAF-Karachi Institute of Economics \& Technology - Marketing, Karachi, Pakistan.
} 
relying on the social media to build good brand image, due to which it is among the most researched topic (Hudson, Roth, Madden, \& Hudson, 2015). This transformation i.e. shifting from traditional to social media is huge than what it was few years ago. In past few years, organizations had ambiguity about the social media use for marketing purposes, now organizations are making huge investments in designing brand and firm related marketing activities on social media. They have their interactive webpages, brand communities and so on (Hudson et al., 2015).

Researchers are putting utmost efforts to understand and explain how the social media is influencing on brands and branding related activities (McAlexander, Kim, \& Roberts, 2003; Keller \& Lehmann, 2006; Smith, Fischer, \& Yongjian, 2012). Due to rapid emergence of technology in last decade, communication patterns have been changed from one-way to two-way communication. In this era of technology users generate contents on social media, related to company and its offerings to significantly influence company's marketing efforts. Companies can use this sophisticated technology to build and maintain strong relationships with their customers (Thackeray, Neiger, Hanson, \& McKenzie, 2008). Consumers have been using social media more frequently with every passing day. Hence, companies have developed their pages on social media to communicate with customers. The social networking websites e.g. Facebook, Youtube, and twitter are getting popularity day by day. Consumers are developing their online brand communities using these websites, whereas companies are also taking the advantage of such communities for marketing their brands (Islam \& Rahman, 2017) and through these online brand communities consumers are connected with each other. They share their ideas, views, experiences and information related to brand (Muniz \& O'guinn, 2001).

Companies establish virtual brand communities to achieve commercial objectives and also to build greater consumer loyalty (Algesheimer, Borle, Dholakia, \& Singh, 2010) and organize different activities and events to deepen and buttress the relationships among online community members (Algesheimer, Dholakia, \& Herrmann, 2005). Consumers join a brand community with different objectives and interests' e.g. psychological need i.e. socially connected feelings; it fulfills sense of belongingness with others when they become the part of the online community (Carlson, Suter, \& Brown, 2008). Community members support and co-create values to other by sharing important and valuable information. Online brand communities affect brand equity and its dimensions (Muniz \& O'guinn, 2001). Researchers' community reviewing the concept with various dimensions, and it is now an exciting topic among researchers over the last decade, especially the online brand communities. Although there are many research streams discussing brand equity and brand equity related concepts in social media settings in various contexts, few researchers attempted to investigate the effect of 'online brand communities' on 'brand equity' of luxury products in fashion industry. Existing research on brand community participation and brand equity in the Pakistan's luxury apparel industry in particular is still sparse. This study investigates the effect of online brand community participation on the dimension of brand equity in the luxury apparel industry. Aggressive growth in fast fashion houses are observed across Asia, and it is expected that average expenditure in fashion industry will be raised by almost $10 \%$ per year. Until the end of 2018, market demand for clothing in Asia was set to reach about 340 billion US\$. In Pakistan the clothing market demand has been recorded as 3,792 
million US\$, and by the end of 2018, the forecasted value was about 4,884 million US\$. This is making the apparel industry in Pakistan very lucrative and leads to higher competition among the firms. This study will provide a logical proof and strategic insights to firm that marketers need to reshape communication strategies. Along with the traditional way of communication, marketers must include social media as their communication tool. They must form and manage the online brand communities.

\section{Literature Review}

It has been observed brand equity is among the most famous and the most studied concepts in marketing literature. Although the concept was developed in 1980s, but get the fame in 1990s when Aaker and Equity (1991) developed the models to explain the concept. Brand equity is defined as "the sum of intangible assets and liabilities linked to the brand". The dimensions of customer based brand equity are 'brand associations', 'brand awareness', 'perceived quality', and 'brand loyalty'. In the above-mentioned dimensions, brand loyalty is considered as the most important dimension. Brand Loyalty is considered as the 'heart' of brand equity, as it develops the core value of brand. Brand loyalty is defined as "the attachment has a customer has to a brand." Loyalty is the bond between customer and brand that customer purchase on routine and regular basis even in situation of strong competition in the same product category. Rich literature is available on antecedents \& consequences of brand equity. Researchers' community in different spans of time studied the concept with different approaches. Academic literature provides the evidence of studying brand equity with several dimensions; concept building and explanation (Aaker \& Equity, 1991); impact of marketing expenses on brand equity (Stahl, Heitmann, Lehmann, \& Neslin, 2012) factors that contribute in leveraging brand equity into brand extension (Bottomley \& Holden, 2001); brand equity outcomes related to product and market i.e. price and revenue premiums, profit premiums, and market share (Goldfarb, Lu, \& Moorthy, 2009; Ailawadi, Lehmann, \& Neslin, 2003); the brand equity's outcomes related to financial market ends i.e. returns, risks, and market value. Current research stream majorly based on how to build and maintain brand equity in social media settings (Islam \& Rahman, 2017).

\section{Brand Community}

The concept of brand communities in marketing literature introduced and defined as 'a specialized, non-geographically bound community, based on a structured set of social relationships among admirers of a brand.' Through a brand community, companies with customers and customers with other customers establish a network of relation. Muniz and O'guinn (2001) explained how brand communities are developed with modern marketing styles. Companies are putting their resources to adopt and learn about brand communities. Technology has given the freedom to customers to start, participate and maintain online brand communities (Brogi et al., 2013). The information shared by community members is strategically relevant to the firms, as it reflects the hidden business opportunities and helps the firms to define the target objectives. The more community members interact with each 
other; the more content is generated, as the customer brand relationship through online social media forums augment the level of customer engagement (A. Bashir \& Ali, 2016). If community members are highly interactive, then they portray their real insights about the company and brand, it might benefit firms in shaping their brand strategies (Casaló, Flavián, \& Guinalíu, 2010). By highly involving in community activities, members presume them an important component of it (Brodie, Ilic, Juric, \& Hollebeek, 2013). Content generated on brand community forum are of great importance, as it is very relevant to brand, consumer, and firm. User generated contents on social media platform positively influence the brand equity dimensions (M. A. Bashir, Ayub, \& Jalees, 2017).

Organizations are considering online brand communities a potential marketing tool. Marvelous business opportunities lies in these online brand communities as consumers' purchasing behavior can effectively be influenced and altered (Adjei, Noble, \& Noble, 2010). These communities also help the organization to increase their understanding of customers by examining the customer generated ideas and opinions (Brogi et al., 2013).

\section{Brand Community \& Brand Equity}

Brand communities have the potential to influence brand equity. It develops heightened brand commitment and brand loyalty as the consumers gathered around the brands through brand communities (Muniz \& O'guinn, 2001; Keller, 2009). According to Muniz and O'guinn (2001) 'a brand with a powerful sense of community would generally have greater value to a marketer than a brand with weak sense of community'. Virtual brand communities are participation in such forums are positively correlated with brand loyalty, and greatly differs among members (Adjei et al., 2010). It has been observed that all the dimension of brand equity are significantly influenced by the activities of brand community (Brogi et al., 2013). Hence, a stronger identification of brand community leads to stronger brand loyalty, whereas other dimension like brand association, brand awareness, and perceived quality also plays their significant role (Muniz \& O'guinn, 2001). Thus, we hypothesized that customers participation in online brand communities positively affect the brand equity components.

H1(a): Brand community participation positively influences the consumers' brand awareness.

H1(b): Brand community participation positively influences the consumers' brand associations.

H1(c): Brand community participation positively influences the consumers' perceived quality of brands.

\section{Relationship between the Dimensions of Brand Equity}

The dimensions of brand equity has already been discussed above, which includes brand association, brand awareness and brand loyalty. All these dimensions are inter-related (Aaker \& Equity, 1991). According to Pappu, Quester, and Cooksey (2005), the nature of relationship is associative, while Martinez, Polo, and De Chernatony (2008) ascertained 
the nature of relationship as causal. The three dimensions of brand equity i.e. perceived quality, brand awareness and associations have consanguine connection with brand appreciation and purchase intention, and ultimately promise the level of brand loyalty. As the perceived quality of brand increases among consumers, their satisfaction level will be more increased. Such consumers will remain loyal to the brand and also recommend this brand to others (Souki \& Goncalves Filho, 2008). Brand loyalty associated with consumer's perceived quality. More positive is the perception about the product quality; more loyalty will be captured by product or brand. Good loyalty status produces favorable associations to brand and vice versa. Similarly, consumers having strong association with a brand have high perceived quality, as both factors are correlated with each other. Initially, brand awareness plays an important role in developing the brand equity, which ultimately leads to the development of brand association (Keller \& Lehmann, 2006) and develops positive perception of the brand upshots perceived quality and brand loyalty (Pappu et al., 2005). Studies also establish the positive association of brand equity with consumer brand preference and purchase intention (M. A. Bashir et al., 2017). Aaker and Equity (1991) considered brand loyalty as the 'heart' of brand. Therefore, we are measuring the impact of other three dimensions on brand loyalty.

H2: Brand Awareness has a significant positive influence on Brand Loyalty.

H3: Brand Association has a significant positive influence on Brand Loyalty.

H4: Perceived Quality has a significant positive influence on Brand Loyalty.

This study proposed a conceptual framework based on Aaker's Brand Equity model by adopting the dimensions of brand equity, except one construct i.e. brand community participation, which has been adopted from another study of Brogi et al. (2013). Figure 1 is presenting the proposed conceptual framework.

\section{Figure 1}

Proposed Conceptual Framework

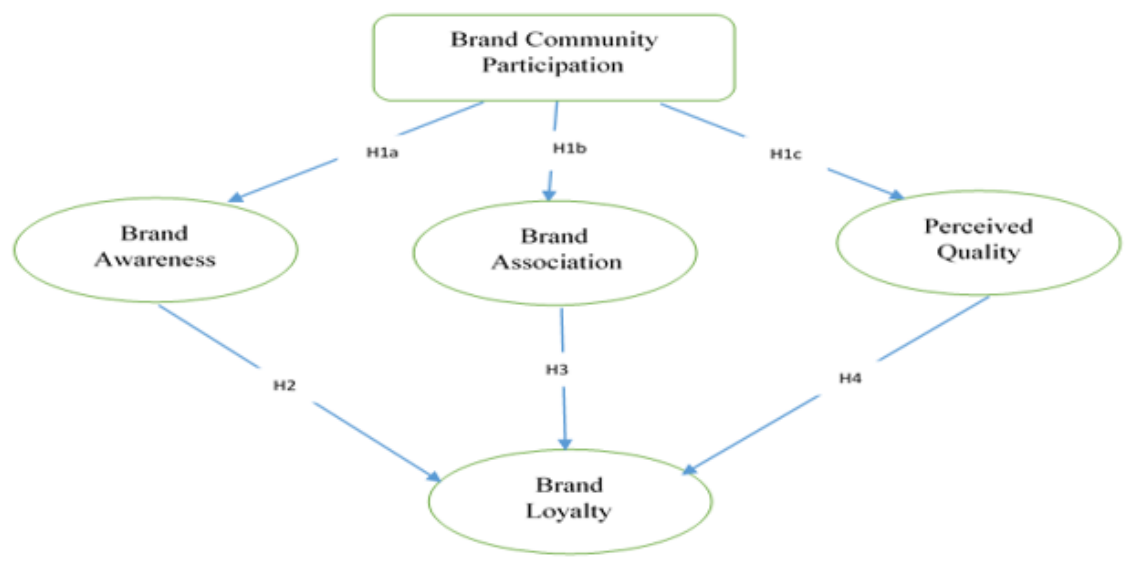




\section{Methodology}

The principal objective of this study was to see the effect of online brand community participation on brand equity. This study is conducted to measure the brand equity of luxury apparel industry in Pakistan. In 2016, the number of internet users in Pakistan were 34.4 million, whereas the number of social media users in Pakistan were approximately 27 million (Digital, Social \& Mobile in APAC, 2016). Fashion industry is the leading industry in terms of fans i.e. more than 28 million (Pakistan Advertising Society, 2016). Luxury apparel brand (product category) was selected to investigate the influence of brand community participation on the dimensions of brand equity. It has been found that majority of social media users fall within the age of 18 to 34 years. Data was collected form the selected business schools. They were enrolled in different business program (from Bachelors, Masters, and Doctorate). Before the questionnaire distribution, students briefed about the online brand communities. Those students were included who liked fashion apparel and posted the comments related to fashion apparel.

For the study, we followed the deductive approach. The conceptual framework (Figure 1) developed in this study is based on the models developed by previous researchers i.e. brand community participation (Brogi et al., 2013), and brand equity dimensions (Yoo, Donthu, \& Lee, 2000). Although constructs used in this study has an established reliability and validity, we re-ascertained the reliability and validity with current data set. Reliability was established through Chronbach alpha, and Composite reliability, while validity established through convergent and discriminant validity. Sample size was 1811. A respondent-to-item (10:1) ratio proposed by Hair, Black, Babin, and Anderson (2009) was considered to calculate the minimum sample size required, however we exceed the ratio of 10:1. Scale items arranged on five point Liker scale. SPSS 23 and AMOS 21 were used for statistical calculations and overall model fit. CFA for each construct was also performed through AMOS.

\section{Results}

Various statistical tests was applied on the collected data, including descriptive statistics, correlation analysis, reliability analysis, CFA, and finally the overall model fit through SEM.

\section{Descriptive Analysis}

Cronbach alpha, Composite reliability and normality of the constructs (through skewness and kurtosis) were re-ascertained. Following table is showing the results.

Perceived quality (PQ) has the highest Cronbach Alpha $(\alpha=0.89)$ followed by brand loyalty (BL) has Cronbach Alpha (i.e $\alpha=0.81$ ). However, brand community participation, brand awareness, and brand association have the same level of internal consistency $(\alpha=0.71)$. It is considered that value of Cronbach alpha greater than 0.7 is acceptable as it maintain the level of internal consistency (Bryman, 2016). When applied SEM, it is recommended to measure latent variable reliability i.e. Composite Reliability (CR) (Raykov, 
1997). The minimum threshold value for CR is 0.7 (Chin, Marcolin, \& Newsted, 2003). Two of the CR values are meeting the minimum threshold value. Acceptable values of 'kurtosis' and 'skewness' lies between \pm 2.5 , this value indicates that these constructs have no issue with univariate normality (Byrne, 2013; Hair Jr, Hult, Ringle, \& Sarstedt, 2016).

Table 1

Descriptive Analysis

\begin{tabular}{lcccccc}
\hline Construct & $\alpha$ & CR & Mean & Std. Dev. & Kurtosis & Skewness \\
\hline Brand Community Participation (BCP) & 0.71 & 0.76 & 2.84 & 1.39 & 0.49 & -0.63 \\
Brand Awareness (BAW) & 0.71 & 0.67 & 5.22 & 1.18 & -0.73 & 1 \\
Brand Association (BA) & 0.71 & 0.69 & 4.23 & 1.13 & -0.49 & 0.3 \\
Perceived Quality (PQ) & 0.89 & 0.85 & 4.96 & 1.29 & -0.64 & 0.12 \\
Brand Loyalty (BL) & 0.81 & 0.67 & 3.45 & 1.38 & 0.32 & -0.51 \\
\hline
\end{tabular}

Table 2

Correlation Analysis

\begin{tabular}{lccccc}
\hline & BCP & BAW & BA & PQ & BL \\
\hline Brand Community Participation (BCP) & 1 & & & & \\
Brand Awareness (BAW) & 0.14 & 1 & & & \\
Brand Association (BA) & 0.3 & 0.44 & 1 & & \\
Perceived Quality (PQ) & 0.24 & 0.55 & 0.52 & 1 & \\
Brand Loyalty (BL) & 0.42 & 0.36 & 0.53 & 0.51 & 1 \\
\hline
\end{tabular}

Factor loadings of indicator variables i.e. Average Variance Extracted (AVE) and criteria of fit indices was used to ascertain the convergent validity. As average variance extracted (AVE) exceeding its minimum threshold value i.e. 0.5 (Hair et al., 2009) and the fit indices are within the prescribed limits, shows constructs qualify convergent validity (Hair Jr et al., 2016). The constructs are distinct and unique since square root of factor loading i.e. average variance extracted is greater than square of each pair of correlation (Fornell \& Larcker, 1981; Hair Jr et al., 2016). Table 3 is showing the discriminant validity of constructs.

Table 3

Discriminant Validity

\begin{tabular}{lccccc}
\hline & BCP & BAW & BA & PQ & BL \\
\hline Brand Community Participation (BCP) & 0.81 & & & & \\
Brand Awareness (BAW) & 0.02 & 0.73 & & & \\
Brand Association (BA) & 0.09 & 0.19 & 0.72 & & \\
Perceived Quality (PQ) & 0.05 & 0.3 & 0.27 & 0.87 & \\
Brand Loyalty (BL) & 0.17 & 0.13 & 0.28 & 0.26 & 0.8 \\
\hline
\end{tabular}

\section{Confirmatory Factor Analysis}

Confirmatory factor analysis for each factor was carried out separately. Summarized results depicted in Table 4. 
Table 4

Confirmatory Factor Analysis

\begin{tabular}{lcccccccccc}
\hline \multicolumn{3}{c}{ Absolute } & \multicolumn{3}{c}{ Relative } & \multicolumn{3}{c}{ Parsimonious } \\
\hline & $\chi^{2}$ & $\chi^{2} / \mathbf{d f}$ & DOF(p) & GFI & AGFI & CFI & NFI & IFI & PNFI & PCFI \\
BCP & 66.2 & 22.06 & $3(.000)$ & 0.98 & 0.94 & 0.94 & 0.97 & 0.97 & 0.48 & 0.48 \\
BAW & 18.18 & 18.18 & $1(.000)$ & 0.99 & 0.96 & 0.99 & 0.99 & 0.99 & 0.33 & 0.33 \\
BA & 45.56 & 23.28 & $2(.000)$ & 0.98 & 0.93 & 0.98 & 0.98 & 0.98 & 0.32 & 0.32 \\
PQ & 39.9 & 19.95 & $2(.000)$ & 0.98 & 0.94 & 0.98 & 0.98 & 0.98 & 0.32 & 0.33 \\
BL & 33.29 & 16.64 & $2(.000)$ & 0.99 & 0.95 & 0.98 & 0.98 & 0.98 & 0.32 & 0.33 \\
Criteria & Low & $<\mathbf{5 . 0}$ & n/a & $>\mathbf{0 . 9 0}$ & $>\mathbf{0 . 9 0}$ & $>\mathbf{0 . 9 0}$ & $>\mathbf{0 . 9 0}$ & $>\mathbf{0 . 9 0}$ & $>\mathbf{0 . 5 0}$ & $>\mathbf{0 . 5 0}$ \\
\hline
\end{tabular}

\section{Emerging Model}

The overall SEM model inclusive of brand community participation, brand awareness, brand association, perceived quality, and brand loyalty is depicted in figure 2. There are four endogenous variables and one exogenous model in the variable. The nine reporting indices are meeting the prescribed criteria limits, and depicted in Table 5:

Table 5

Fit Indices

\begin{tabular}{lcccccccccc}
\hline & \multicolumn{3}{c}{ Absolute } & & \multicolumn{3}{c}{ Relative } & \multicolumn{3}{c}{ Parsimonious } \\
\hline & $\chi^{2}$ & $\chi^{2} / \mathbf{d f}$ & DOF(p) & GFI & AGFI & CFI & NFI & IFI & PNFI & PCFI \\
\hline Overall Model & 652.634 & 12.797 & $51(.000)$ & 0.936 & 0.903 & 0.925 & 0.92 & 0.925 & 0.711 & 0.715 \\
Criteria & Low & $<\mathbf{5 . 0}$ & n/a & $>\mathbf{0 . 9 0}$ & $>\mathbf{0 . 9 0}$ & $>\mathbf{0 . 9 0}$ & $\mathbf{> 0 . 9 0}$ & $>\mathbf{0 . 9 5}$ & $>\mathbf{0 . 5 0}$ & $>\mathbf{0 . 5 0}$ \\
\hline
\end{tabular}

\section{Figure 2}

Overall Model

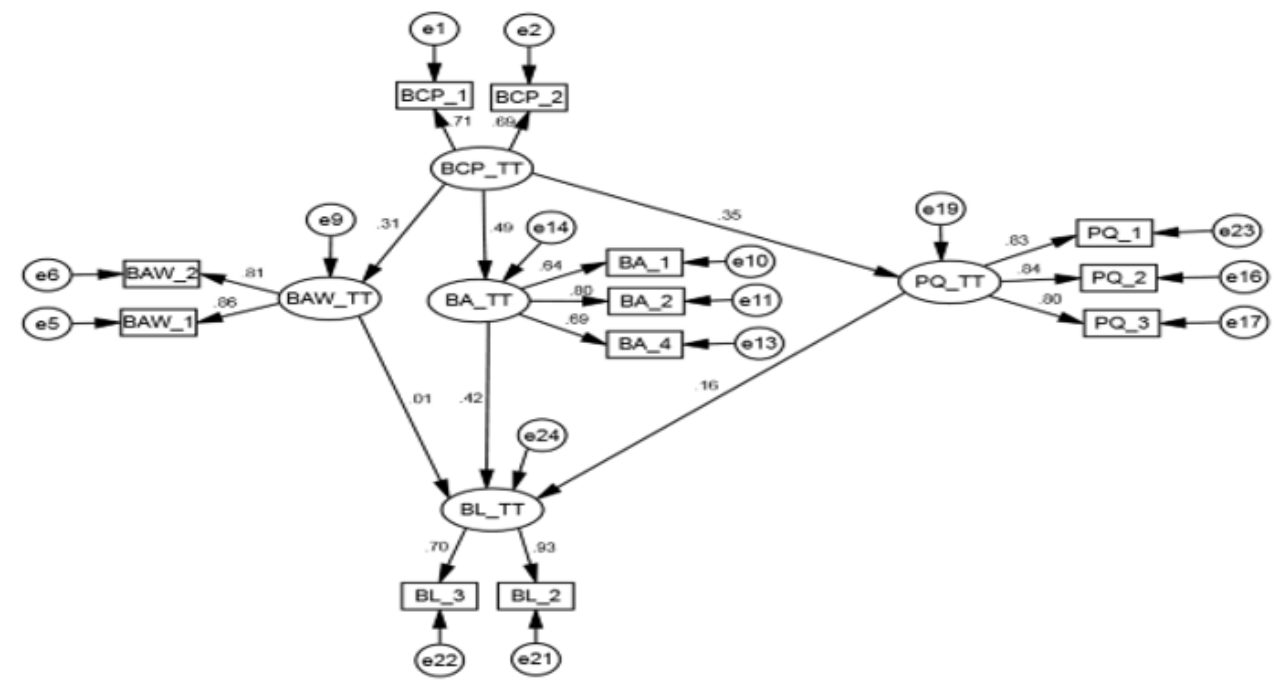

In absolute category $\chi^{2}=652.634, \mathrm{DF}=51, \mathrm{p}=0.000>.05, \mathrm{GFI}=0.936>0.90$, and $\mathrm{AGFI}=0.903>0.90$ are significant. In relative category $\mathrm{CFI}=0.925>0.900, \mathrm{NFI}=0.920$ $>0.900$ meets prescribed requirements. In Parsimonious category PNFI $=0.711>.0 .50$ 
and PCFI $=0.715>0.50$ are within the prescribed criteria. Model fit can be considered good as majority of the fit indices are meeting the prescribed limits. RMSEA for the model is 0.08 , which is meeting the upper threshold value. Chi Square statistics $\left(\chi^{2}\right)$ is sensitive to sample size, and is mostly not relied upon as a basis for acceptance or rejection for model fit (Iacobucci, 2010).

\section{Hypothesis Testing and Results}

Table 6 is showing the SEM output for hypothesis derived for the study, including standardized regression weights and critical values. Among six hypotheses, five hypotheses were accepted.

\section{Figure 3}

Overall Model

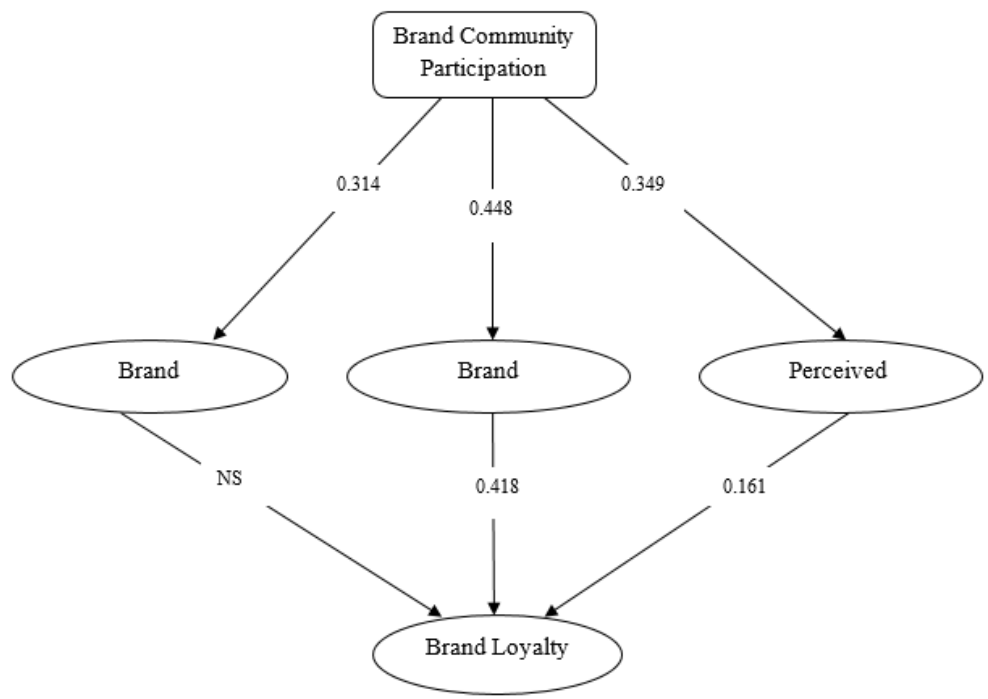

Table 6

Summary of Hypothesized Relationships

\begin{tabular}{lllllll}
\hline \multicolumn{2}{c}{ Relationship } & SRW & SE & CR & P \\
\hline Brand Awr & $<-$ & Brand Com Prtc & 0.314 & 0.041 & 10.188 & $* * *$ \\
Brand Ass & $<-$ & Brand Com Prtc & 0.488 & 0.031 & 13.679 & $* * *$ \\
Per Qual & $<-$ & Brand Com Prtc & 0.349 & 0.037 & 11.552 & $* * *$ \\
Brand Loyt & $<-$ & Brand Awr & 0.01 & 0.025 & 0.401 & 0.689 \\
Brand Loyt & $<-$ & Brand Ass & 0.418 & 0.046 & 13.919 & $* * *$ \\
Brand Loyt & $<-$ & Per Qual & 0.161 & 0.028 & 6.364 & $* * *$ \\
\hline
\end{tabular}

It is evident from the results that brand community participation strongly predicts brand association, and in turn brand association strongly predict brand loyalty. 


\section{Discussion, Limitations, Future Research and Implica- tions}

This study aimed to measure the influence of 'brand community participation' on the dimensions of 'brand equity'. The information provided by the brand users through this sort of platforms can augment the other customers' overall attitude about the brand, as they consider this information credible and trustworthy (Pornpitakpan, 2004).

Findings of the study are consistent to some earlier studies (Brogi et al., 2013; Capece \& Campisi, 2013). The findings of the study are of great importance for clothing fashion brands in Pakistan. A brand could be in trouble, if the customers lead the communication. Organizations, by making their presence in OBCs, can get deeper insides from customers, which ultimately help the firms to make better strategies for brand success. When consumers become members of online brand communities, they start contributing in the activities of that community. They discuss and share their feelings, opinions and experience about the brand. This whole discussion through online brand communities enhance the brand and customer association, increase the other customers' awareness about the brand, and develop and modify the overall brand quality perception (Brogi et al., 2013). Since brand loyalty has been considered as the most important factor contributing to the brand equity, the impact of other three dimension of brand equity was also measured on brand loyalty. Brand association and perceived quality positively influenced brand loyalty (Pappu et al., 2005; Keller \& Lehmann, 2006). Consumer brand association reflects through brand community joining, participation in community activities' as consumer view himself as the integral part of the community. Consumers among each other share the brand related information. The content quality then ultimately develops a quality perception of the brand. Good perception about the brand create favorable, unique, and strong loyalty for the brand (Yoo et al., 2000). As per the findings of this study, the impact of brand awareness on brand loyalty is insignificant. It indicates that if consumer is aware of the brand it has no link the loyalty. For brand loyalty, it is necessary a consumer have brand experience, strong and positive association with the brand and must have good and favorable perception about the brand quality. Other studies also figured out that impact of brand awareness sometime found insignificant on brand equity.

The study is limited to one metropolitan city of Pakistan i.e. Karachi. As the data was collected only from Karachi, hence the generality of the study is limited, although Karachi has the strong representation of different subcultures and races. Future research include more cities. Data was collected form the students of business schools based on the published report (Pakistan Advertising Society, 2016) that majority of the users on social media are ranges between 18 to 34 years of age. Future research may include other specific age groups. Study was performed on luxury apparel industry and the findings are only limited to this domain. Future research may include other industries and can be performed in cross industry analysis context. This study is a quantitative analysis. Qualitative analysis may give more or different insights about the phenomenon.

This study contributes in investigating the influence of brand community activities on brand association, which has been found significant. The relationship between both constructs elevates the perception of the customers about brand. Managers by creating 
brand communities and by motivating customers to positively participate in their brand community, can enhance and strengthen the brand image. Customers' participation in online communities can be increased, when companies give certain incentives to some loyal and more participative customers. Even if a consumer is writing something negative about the brand, it can help the organization to make correction in the perception of the brand or make some changes in the brand even if it is necessary. Organizations may deploy a full time manager e.g. 'brand community manager' to start, maintain and augment the customer relationship using online brand communities. 


\section{References}

Aaker, D. A., \& Equity, M. B. (1991). Capitalizing on the value of a brand name. New York, 28(1), 35-37.

Adjei, M. T., Noble, S. M., \& Noble, C. H. (2010). The influence of C2C communications in online brand communities on customer purchase behavior. Journal of the Academy of Marketing Science, 38(5), 634-653.

Ailawadi, K. L., Lehmann, D. R., \& Neslin, S. A. (2003). Revenue premium as an outcome measure of brand equity. Journal of Marketing, 67(4), 1-17.

Akrout, H., \& Nagy, G. (2018). Trust and commitment within a virtual brand community: The mediating role of brand relationship quality. Information $\&$ Management, 55(8), 939-955.

Algesheimer, R., Borle, S., Dholakia, U. M., \& Singh, S. S. (2010). The impact of customer community participation on customer behaviors: An empirical investigation. Marketing Science, 29(4), 756-769.

Algesheimer, R., Dholakia, U. M., \& Herrmann, A. (2005). The social influence of brand community: Evidence from european car clubs. Journal of Marketing, 69(3), 19-34.

Bashir, A., \& Ali, N. A. (2016). Impact of customer brand relationship through facebook on the level of customer engagement. Pakistan Business Review, 18(1), 159-178.

Bashir, M. A., Ayub, N., \& Jalees, T. (2017). The impact of the firm generated contents and the user generated contents through social media on brand equity elements. Pakistan Business Review, 19(3), 744-760.

Bottomley, P. A., \& Holden, S. J. (2001). Do we really know how consumers evaluate brand extensions? Empirical generalizations based on secondary analysis of eight studies. Journal of Marketing Research, 38(4), 494-500.

Brodie, R. J., Ilic, A., Juric, B., \& Hollebeek, L. (2013). Consumer engagement in a virtual brand community: An exploratory analysis. Journal of Business Research, 66(1), 105-114.

Brogi, S., Calabrese, A., Campisi, D., Capece, G., Costa, R., \& Di Pillo, F. (2013). The effects of online brand communities on brand equity in the luxury fashion industry. International journal of engineering business management, 5, 5-32.

Bryman, A. (2016). Social research methods. Oxford university press.

Byrne, B. M. (2013). Structural equation modeling with LISREL, PRELIS, and SIMPLIS: Basic concepts, applications, and programming. Psychology Press.

Capece, G., \& Campisi, D. (2013). User satisfaction affecting the acceptance of an elearning platform as a mean for the development of the human capital. Behaviour $\&$ Information Technology, 32(4), 335-343.

Carlson, B. D., Suter, T. A., \& Brown, T. J. (2008). Social versus psychological brand community: The role of psychological sense of brand community. Journal of Business Research, 61(4), 284-291.

Casaló, L. V., Flavián, C., \& Guinalíu, M. (2010). Relationship quality, community promotion and brand loyalty in virtual communities: Evidence from free software communities. International Journal of Information Management, 30(4), 357-367. 
Chin, W. W., Marcolin, B. L., \& Newsted, P. R. (2003). A partial least squares latent variable modeling approach for measuring interaction effects: Results from a monte carlo simulation study and an electronic-mail emotion/adoption study. Information Systems Research, 14(2), 189-217.

Fornell, C., \& Larcker, D. F. (1981). Structural equation models with unobservable variables and measurement error: Algebra and statistics. Sage Publications Sage CA: Los Angeles, CA.

Goldfarb, A., Lu, Q., \& Moorthy, S. (2009). Measuring brand value in an equilibrium framework. Marketing Science, 28(1), 69-86.

Hair, J., Black, W., Babin, B., \& Anderson, R. (2009). Multivariate data analysis 7th edition. Pearson Prentice Hall.

Hair Jr, J. F., Hult, G. T. M., Ringle, C., \& Sarstedt, M. (2016). A primer on partial least squares structural equation modeling (PLS-SEM). Sage publications.

Hudson, S., Roth, M. S., Madden, T. J., \& Hudson, R. (2015). The effects of social media on emotions, brand relationship quality, and word of mouth: An empirical study of music festival attendees. Tourism Management, 47, 68-76.

Iacobucci, D. (2010). Structural equations modeling: Fit indices, sample size, and advanced topics. Journal of Consumer Psychology, 20(1), 90-98.

Islam, J. U., \& Rahman, Z. (2017). The impact of online brand community characteristics on customer engagement: An application of stimulus-organism-response paradigm. Telematics and Informatics, 34(4), 96-109.

Keller, K. L. (2009). Building strong brands in a modern marketing communications environment. Journal of Marketing Communications, 15(2-3), 139-155.

Keller, K. L., \& Lehmann, D. R. (2006). Brands and branding: Research findings and future priorities. Marketing Science, 25(6), 740-759.

Laroche, M., Habibi, M. R., \& Richard, M.-O. (2013). To be or not to be in social media: How brand loyalty is affected by social media? International Journal of Information Management, 33(1), 76-82.

Martinez, E., Polo, Y., \& De Chernatony, L. (2008). Effect of brand extension strategies on brand image. International Marketing Review. doi: 10.1108/02651330810851908

McAlexander, J. H., Kim, S. K., \& Roberts, S. D. (2003). Loyalty: The influences of satisfaction and brand community integration. Journal of Marketing Theory and Practice, 11(4), 1-11.

Muniz, A. M., \& O'guinn, T. C. (2001). Brand community. Journal of Consumer Research, $27(4), 412-432$.

Ngai, E. W., Tao, S. S., \& Moon, K. K. (2015). Social media research: Theories, constructs, and conceptual frameworks. International Journal of Information Management, 35(1), 33-44.

Pappu, R., Quester, P. G., \& Cooksey, R. W. (2005). Consumer-based brand equity: improving the measurement-empirical evidence. Journal of Product E Brand Management. doi: 10.1108/10610420510601012

Pornpitakpan, C. (2004). The persuasiveness of source credibility: A critical review of five decades' evidence. Journal of Applied Social Psychology, 34(2), 243-281. 
Raykov, T. (1997). Estimation of composite reliability for congeneric measures. Applied Psychological Measurement, 21(2), 173-184.

Smith, A. N., Fischer, E., \& Yongjian, C. (2012). How does brand-related user-generated content differ across YouTube, Facebook, and Twitter? Journal of Interactive Marketing, 26(2), 102-113.

Souki, G. Q., \& Goncalves Filho, C. (2008). Perceived quality, satisfaction and customer loyalty: An empirical study in the mobile phones sector in Brazil. International Journal of Internet and Enterprise Management, 5(4), 298-312.

Stahl, F., Heitmann, M., Lehmann, D. R., \& Neslin, S. A. (2012). The impact of brand equity on customer acquisition, retention, and profit margin. Journal of Marketing, 76(4), 44-63.

Thackeray, R., Neiger, B. L., Hanson, C. L., \& McKenzie, J. F. (2008). Enhancing promotional strategies within social marketing programs: Use of Web 2.0 social media. Health Promotion Practice, 9(4), 338-343.

Yoo, B., Donthu, N., \& Lee, S. (2000). An examination of selected marketing mix elements and brand equity. Journal of the Academy of Marketing Science, 28(2), 195-211. 